\title{
The effect of inoculants and cellulase on the fermentation and microbiological composition of grass silage. I Biochemical changes in the silages
}

\author{
AINO RAURAMAA, JOUKO SETÄLÄ and TAUNO MOISIO \\ Valio Co-operative Dairies' Association, \\ Research and Development Department \\ P.O. Box 176, SF-00181 Helsinki, Finland \\ TERTTU HEIKKILÄ and MARTTI LAMPILA \\ Agricultural Research Centre, \\ Department of Animal Husbandry \\ 31600 Jokioinen, Finland
}

\begin{abstract}
The effect of the inoculation and the adding of the cellulase enzyme on the fermentation of sugar-rich, direct cut grass were studied. The control silages were made by using AIV II solution and no additives. The silages were prepared from the first cut on a farm scale in the summer of 1985.

Generally all four silages were organoleptically good. The results showed only minor differences in the fermentation between untreated and inoculated or enzyme silages. The quality of fermentation, however, was improved in inoculated and enzyme silages. The quality further improved by using the AIV II solution. This was supported by the changes in the $\mathrm{pH}$, ammonia, buffering capacity, redox potential, temperature and finally by a better digestibility of organic matter.
\end{abstract}

Index words: Silage preservation, inoculants and enzyme, biochemical changes

\section{Introduction}

The AIV fodder preservation method is based on the control of fermentation by the addition of acid. At the same time the respiration losses during the initial stages of the silage making can be reduced. The $\mathrm{pH}$ of fodder must be lowered quickly below 4 and kept there (Virtanen 1933, Heikonen et al. 1979).

Strong acids are hazardous to handle and corrosive to machinery. Therefore alternative means to achieve rapid acidification have 
been long searched for. The use of a cellulase enzyme in the ensiling was proposed in a German patent in 1940 (LeAterwood et al. 1963).

Cellulase and other cellulolytic enzymes are used for converting cell-wall material into sugars, which are used as a source of energy by the lactic acid bacteria. Research has already shown that different cellulolytic preparations vary markedly in their ability to solubilize cell-wall material. This ability depends on the producer micro-organisms of the enzymes (Autrey et al. 1975, Henderson and McDonald 1977, Vaisto et al. 1978) and the rate of the application of the enzymes (Autrey et al. 1975, Nehring et al. 1983).

To ensure a rapid reduction of $\mathrm{pH}$ caused by homofermentative lactic acid fermentation inoculants have been added to the grass. This implies that an adequate amount of survial lactic acid bacteria be added (ROOKE et al. 1985). The lactic acid bacteria must be able to grow quickly, to dominate during the first hours of ensiling and to produce pure lactic acid. Further, the bacteria should tolerate variations in temperature, humidity and acidity, and they shouldn't have proteolytic activity (WOOLFord and SAwCZYC $1984 \mathrm{a}, \mathrm{b}$, Vanbelle and Bertin 1985).

It is known that lactic acid bacteria need water-soluble carbohydrates to produce lactic acid (WoOlford 1984). The experiment reported here was designed to study the effect of an adequate inoculation and the adding of the cellulase enzyme on the fermentation of sugar-rich direct cut grass. The control silages were made by using AIV II solution and no additives. The silages were prepared from the first cut on a farm scale in the summer of 1985 .

\section{Materials and methods}

\section{Experimental design}

The silages were carried out in bunker silos at the Agricultural Research Centre, Jokioinen, on the 16th and 17th June, 1985.
Mainly cooksfoot (Dactylis glomerata) and timothy (Phléum pratense) grass (in ratio 1:2) was harvested from six different fields with four flail harvesters. The amount of each silage made was about $45000 \mathrm{~kg}$. The application of the preservatives was made in the harvester while cutting the grass. The experimental silages were as follows:

1. AIV II solution

(80\% formic acid, $2 \%$ orthophosphoric acid, $5.2 \mathrm{l} /$ ton grass)

2. No additives

3. Inoculant $\mathrm{L}$

(Lactobacillus plantarum) $7 \times 10^{11} \mathrm{cfu} / \mathrm{ton}$ grass

4. Enzyme cellulase

(Trichoderma viride/reesei) $8.9 \times 10^{6} \mathrm{IU} /$ ton grass

The silages were made at the same time. Two silages were ensiled in one silo. The silages were separated by a plastic cover which reached from the bottom to the top. The fodders were compacted by tractors, covered carefully by plastic and pressed with sawdust.

\section{Sampling}

Four grass samples for the determination of the microbiological composition were cut from the whole field area. Representative fodder samples of the raw material were collected from the different wagon loads.

The samples from the silages were taken by coring 9 times during the preservation period. The preservation period was 174 days. The samples were transported to the laboratory in styrox boxes containing crushed ice.

Part of the sample was dried for chemical analyses at $50^{\circ} \mathrm{C}$ overnight and milled by a sample mill (Tecator AB, Sweden) using a $1 \mathrm{~mm}$ screen. Press juice was also squeezed from the sample. All fresh samples were kept frozen.

\section{Chemical methods}

From the pressed juice of the sample the following determinations were made: 
Hydrogen ion activity $(\mathrm{pH})$ was determined with a glass electrode and nitrate by using a nitrate specific electrode. Ammonium ions were analyzed in a Kone $\mathrm{CD}$ analyzer by using a colorimetric method, where the ammonium ions react with phenol and hypochlorite to give a blue compound which is measured at $620 \mathrm{~nm}$.

Volatile fatty acids were determined by gas chromatography: column $10 \%$ SP-1200 and $1 \% \mathrm{H}_{3} \mathrm{PO}_{4}$ Chromosorb AW, 80-100 mesh. L- and D-lactic acids were determined enzymatically (Boehringer Mannheim $\mathrm{GmbH}$ ). Other organic acids were analyzed by HPLC, using a column packed with a strong ion exchanger, eluted by $0.006 \mathrm{~N} \mathrm{H}_{2} \mathrm{SO}_{4}$ and detected UV $210 \mathrm{~nm}$. Amines were analyzed as chloronitro-benzofurazan derivatives by HPLC (Imai and Watanable 1981, Ghosh and WHITEHOUSE 1968).

From the fresh fodder the following determinations were made:

Dry matter was determined by drying the sample at $105^{\circ} \mathrm{C}$ overnight. Glucose, fructose and sucrose were determined by an enzymatic method (Boehringer Mannheim $\mathrm{GmbH}$ ). Total buffering capacity ( $\mathrm{pH} \mathrm{4-6)}$ of the grass and silages was determined by using a method by Playne and McDonald (1966).

From the dried sample the following determinations were made:

Ash was ignitted in a muffle oven at $600^{\circ} \mathrm{C}$ overnight. Total nitrogen was determined by digesting the sample at $360^{\circ} \mathrm{C}$ catalyzed by Kjeltabs Auto $\left(1.5 \mathrm{~g} \mathrm{~K}_{2} \mathrm{SO}_{4}\right.$ and $0.0075 \mathrm{~g}$ $\mathrm{Se}$ ) in a Tecator-Digestor-microdigestion system. Total sugar calculated as glucose was determined by Somogyı's (1945) titration method. Crude fibre was determined by the Weende method. The digestibility of organic matter in vitro was determined by using the Menke method (Steingass, 1983).

In the silo the following measurements were taken:

Temperature in the silages during the preservation period was measured by resistance thermometers manufactured by Wallac Oy. According to Molsio (1979) carbon dioxide was estimated by absorbing the gas sample in a $5 \mathrm{~N} \mathrm{KOH}$ solution and the redox potential was measured with a gold electrode method. The temperature, carbon dioxide and redox potential measurements were made from three different locations in each silage.

\section{Results and discussion}

The odour of the silages was sour and the colour yellowish-green, which according to Heikonen et al. (1979) means that all four silages were organoleptically good. The $\mathrm{pH}$ of all the silages was below 4 . The ammonia content, ammonia- $\mathrm{N}$ as $\%$ from the total $\mathrm{N}, 2.8-$ $6.3 \%$, was low, when it was compared with the values of Breirem and Ulvesli (1960), $5-7 \%$ for good quality silage. In three highly fermented silages in which inoculants, cellulase or no additives had been used, the sugar content was low. There were clear differences in the fermentation patterns between various experimental silages.

pH, sugars, organic acids, alcohols, buffering capacity

The addition of AIV II solution, $5.2 \mathrm{l} /$ ton grass reduced immediately the $\mathrm{pH}$ of fresh cut fodder mass from 6.2 to 4.2 . The reduction of the $\mathrm{pH}$ below 4 in AIV II silage was reached in four weeks by slow fermentation. In other silages the decrease of the $\mathrm{pH}$ below 4 was caused by vigorous fermentation using sugars in the fodder during one week. In each silage the $\mathrm{pH}$ also remained at an acceptable level during the whole preservation period. The lowest $\mathrm{pH}$ value, 3.74 , was detected in the cellulase-treated silage (Fig. 1).

The lower $\mathrm{pH}$ value of the cellulase treated silage, compared with the untreated and inoculant silages, indicated that the enzyme had decomposed crude fibre of the silage during the preservation (Table 1, Fig. 1). However, the sugar content was only slightly higher in the enzyme-treated silage (Fig. 1). The sugar produced had been fermented by lactic acid bacteria (RAURAMAA et al. 1987). 

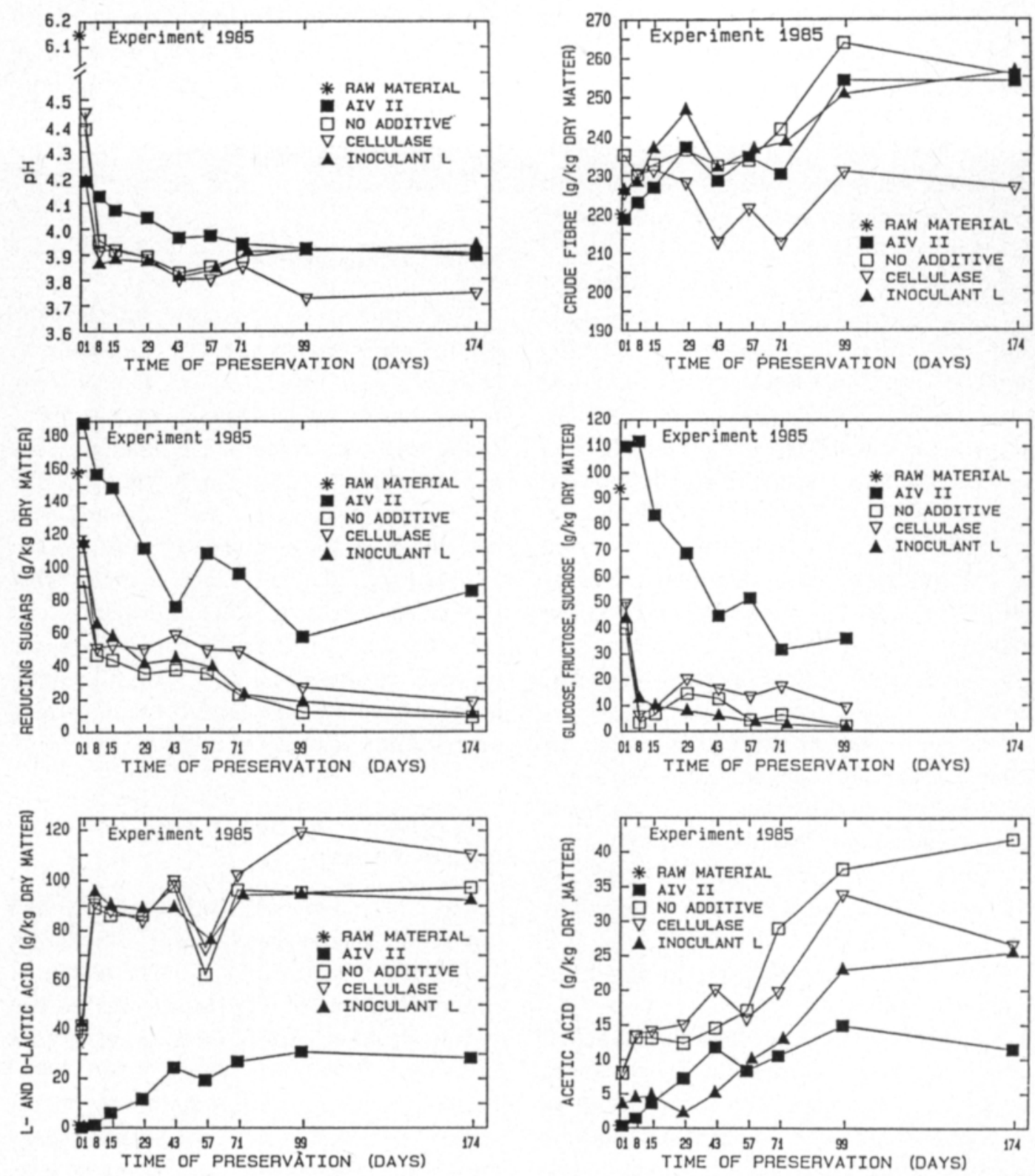

Fig. 1. The chemical changes in the experimental silages made with AIV II solution, no additives, cellulase and inoculant.

These findings are in agreement with those of Henderson and McDonald (1977), Nehring et al. (1983) and SEALE et al. (1986).

Only small amounts of volatile fatty acids were produced compared with lactic acid (Fig. 1). The amount of acetic acid began to rise, when the concentration of lactic acid in the silages was about $8-10 \%$ of the dry matter. It is possible that inhibition of the end product may occur in this lactic acid concentration. The species of bacteria or their metabolism can change which is seen as growing acetic acid production and slight loss of lactic acid in one silage. Lactic acid formed by micro-organisms consisted of both $\mathrm{L}(+)$ and $\mathrm{D}(-)$-forms, the respective relations of 

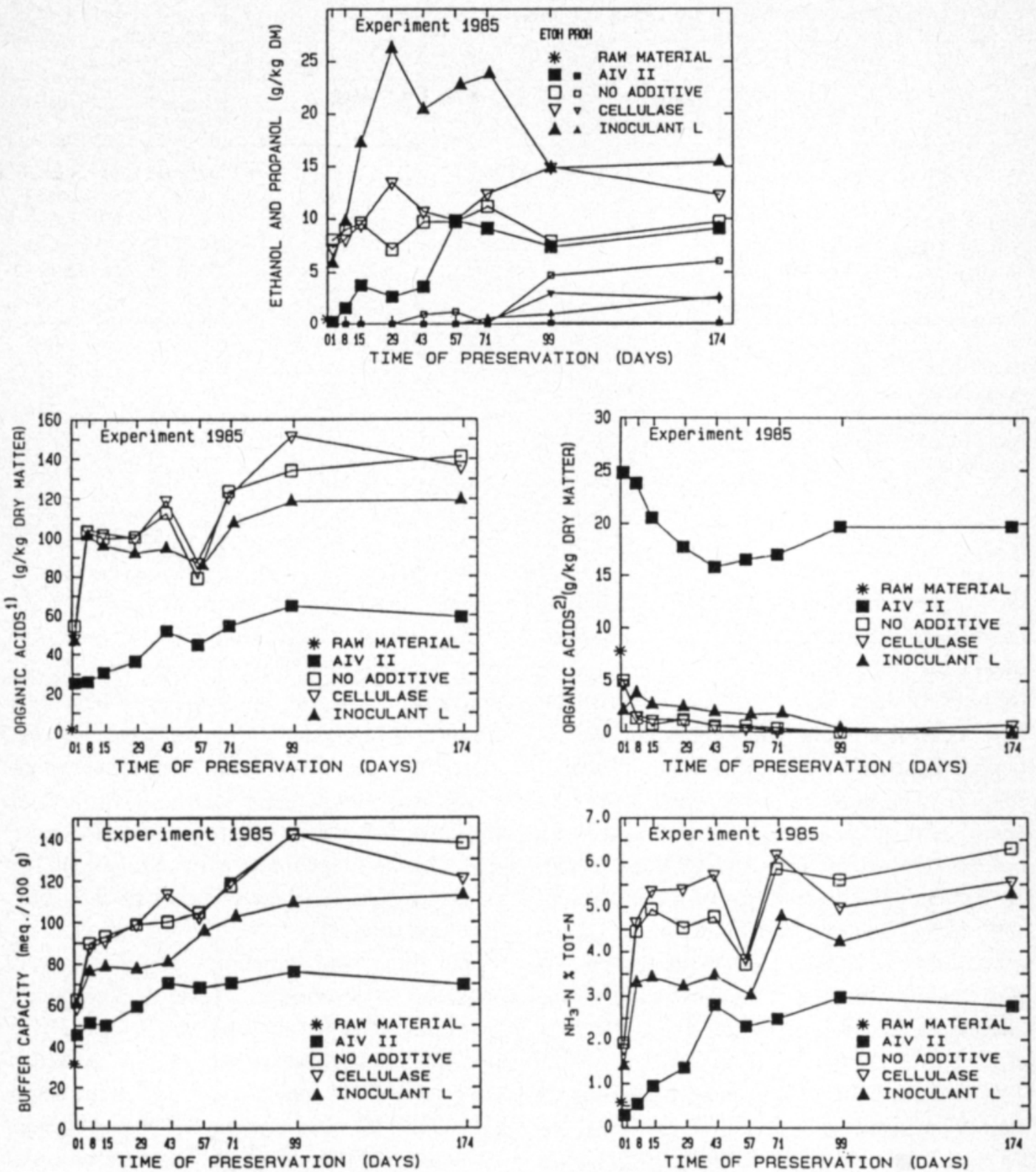

Fig. 2. The chemical changes in the experimental silages made with AIV II solution, no additives, cellulase and inoculant. Organic acids (1) are fumaric, aconitic, citric, formic, lactic, acetic and propionic acids. Organic acids (2) are fumaric, aconitic, citric and formic acids.

which were 1.23 in cellulase treated silage, 1.14 in untreated silage, 1.04 in inoculated silage and 0.98 in AIV II silage. The greater amount of $\mathrm{L}(+)$-isomer of lactic acid would show that in the cellulase-treated and untreated silages there have been activities of homolactic strains of Streptococci faecalis, S. faecium and Lactobacillus casei. These strains produce $\mathrm{L}(+)$-isomer of lactic acid in silages according to VANBELLE et al. (1985).

The ratio of lactic acid to acetic acid was 4.1 in the cellulase-treated silage. The respective figure was 3.6 in inoculated silage, 2.4 in AIV II silage and 2.3 in untreated silage. Judged by these figures the fermentation in the cellulase and inoculated silages was pure 
Table 1. Composition of silages at the end of the preservation period.

\begin{tabular}{|c|c|c|c|c|c|c|}
\hline & & \multicolumn{5}{|c|}{ Preservative } \\
\hline & & $\begin{array}{c}\text { Raw } \\
\text { material }\end{array}$ & AIV II & $\begin{array}{c}\text { No } \\
\text { additive }\end{array}$ & Cellulase & Inoculant \\
\hline Dry matter & $\%$ & 20.3 & 23.2 & 20.4 & 20.3 & 20.7 \\
\hline $\mathrm{pH}$ & & 6.12 & 3.89 & 3.90 & 3.74 & 3.93 \\
\hline $\mathrm{NH}_{3}-\mathrm{N} \%$ tot $-\mathrm{N}$ & & 0.3 & 2.8 & 6.3 & 5.6 & 5.3 \\
\hline Ash & $\mathrm{g} / \mathrm{kg} \mathrm{DM}$ & 70.3 & 62.6 & 71.3 & 64.5 & 66.0 \\
\hline Crude fibre & $\mathrm{g} / \mathrm{kg} \mathrm{DM}$ & 219.4 & 254.0 & 255.5 & 226.0 & 256.7 \\
\hline Crude protein & $\mathrm{g} / \mathrm{kg} \mathrm{DM}$ & 175.6 & 177.8 & 182.7 & 177.6 & 182.8 \\
\hline Reducing sugars & $\mathrm{g} / \mathrm{kg} \mathrm{DM}$ & 155.9 & 85.8 & 8.5 & 18.0 & 10.2 \\
\hline Nitrate & $\mathrm{g} / \mathrm{kg} \mathrm{DM}$ & 1.78 & 1.68 & 1.08 & 1.18 & 1.16 \\
\hline Lactic acid & $\mathrm{g} / \mathrm{kg} \mathrm{DM}$ & 0.4 & 27.4 & 95.9 & 108.8 & 91.7 \\
\hline Acetic acid & $\mathrm{g} / \mathrm{kg} \mathrm{DM}$ & 0.3 & 11.3 & 41.3 & 26.5 & 25.2 \\
\hline Propionic acid & $\mathrm{g} / \mathrm{kg} \mathrm{DM}$ & 0 & 0.7 & 4.8 & 0.9 & 3.0 \\
\hline Butyric acid & $\mathrm{g} / \mathrm{kg} \mathrm{DM}$ & 0 & 0 & 0 & 0 & 0 \\
\hline Ethanol & $\mathrm{g} / \mathrm{kg} \mathrm{DM}$ & 0.2 & 8.9 & 9.5 & 11.9 & 15.3 \\
\hline
\end{tabular}

lactic acid fermentation. However, according to the Gibson tests the frequency of homofermentative lactic acid bacteria was greatest in the AIV II silage (see RauramaA et al. 1987). The alcohol content was highest in the inoculated and cellulase treated silages (Table 1, Fig. 2). The conversion of lactic acid into acetic acid or ethanol was also found in an earlier experiment of ours (SETÄLÄ et al. 1987). Though the amounts of alcohols were slight, they were connected with the occurrence of yeasts in the silages at the end of the ensiling process. This observation was already made in our earlier trials (SETÄLA et al. 1987).

LiNDGREN et al. (1985) have found yeasts mainly in formic acid-treated silages. Then the formic acid treatment has been below $3 \mathrm{~kg}$ per ton grass.

Organic acids formed in plants decreased rapidly during the fermentation (Fig. 2). After the first day of preservation there was $17 \mathrm{~g} / \mathrm{kg}$ formic acid and $8 \mathrm{~g} / \mathrm{kg}$ other organic acids in AIV II silage. According to Dellaglio (1985) micro-organisms in silage are able to use organic acids: citric-, fumaric- and aconitic acids, because their amount decreased when the fermentation proceeded.

Lactic and acetic acids and their salts were responsible for most of the buffering capaci- ties of the silages. In all the silages the buffering capacities increased during the preservation. The buffering capacity value on aqueous macerates of the mixture of cocksfoot and timothy sward was $28.7 \mathrm{meq} / 100 \mathrm{~g}$ of dry matter between $\mathrm{pH} 4$ and 6 . The highest value $130.6 \mathrm{meq} / 100 \mathrm{~g}$ of dry matter was found in the untreated silage, the respective figure being 120.9 in the silage made with cellulase, 111.6 in the inoculated silage and only 68.8 in AIV II silage (Fig. 2).

The buffering capacities correlated well with the total amounts of the organic acids measured from the silages $\left(\mathrm{R}=0.83^{* * *}\right.$, $\mathrm{n}=40$ ). The correlation between the buffering capacity and the sum of lactic and acetic acids $\left(\mathrm{R}=0.94^{* * *}\right)$ was significant. The correlation between the buffering capacity and ammonia nitrogen $\left(\mathrm{R}=0.93^{* * *}\right)$ was also significant. As the variations of the ammonia contents were very narrow, this correlation was not important. Playne and McDonald (1966) have estimated that the buffering capacity caused by plant proteins was $10-20 \%$ of the total buffering capacity between $\mathrm{pH} 4$ and 6. We did not find any good correlation between amines and buffering capacities $\left(\mathrm{R}=0.67^{* * *}\right)$.

The digestibility of the organic matter in vitro was only slightly different in the silages 
Table 2. The amine content of silages after 174 days of preservation.

\begin{tabular}{lcccccc}
\hline Preservative & $\begin{array}{c}\text { Tyramine } \\
\text { g/kg DM }\end{array}$ & $\begin{array}{c}\text { Putrescine } \\
\mathrm{g} / \mathrm{kg} \mathrm{DM}\end{array}$ & $\begin{array}{c}\text { Cadaverine } \\
\mathrm{g} / \mathrm{kg} \mathrm{DM}\end{array}$ & $\begin{array}{c}\text { Tryptamine } \\
\mathrm{g} / \mathrm{kg} \mathrm{DM}\end{array}$ & $\begin{array}{c}\text { Phenylethyl- } \\
\text { amine } \\
\mathrm{g} / \mathrm{kg} \mathrm{DM}\end{array}$ & $\begin{array}{c}\text { Sum of } \\
\text { amines } \\
\mathrm{g} / \mathrm{kg} \mathrm{DM}\end{array}$ \\
\hline Raw material & 0 & 0.01 & 0 & 0 & 0 & 0.01 \\
AIV II & 1.41 & 0.18 & 0.18 & 0.06 & 0 & 1.83 \\
No additive & 1.29 & 0.67 & 0.78 & 0 & 0.01 & 2.75 \\
Cellulase & 0.92 & 0.36 & 0.32 & 0 & 0 & 1.60 \\
Inoculant & 0.10 & 0.63 & 0.77 & 0 & 0 & 1.50 \\
\hline
\end{tabular}

(Fig. 3). However, this experiment supported our earlier finding (SETÄLÃ et al. 1986) that the organic matter digestibility in untreated, inoculated or enzyme treated silages was lower than in the AIV II treated silage.

\section{Amines, ammonia and nitrate}

The formation of amines was not very remarkable. In the silages made without additives and with cellulase, tyramine, putrescine
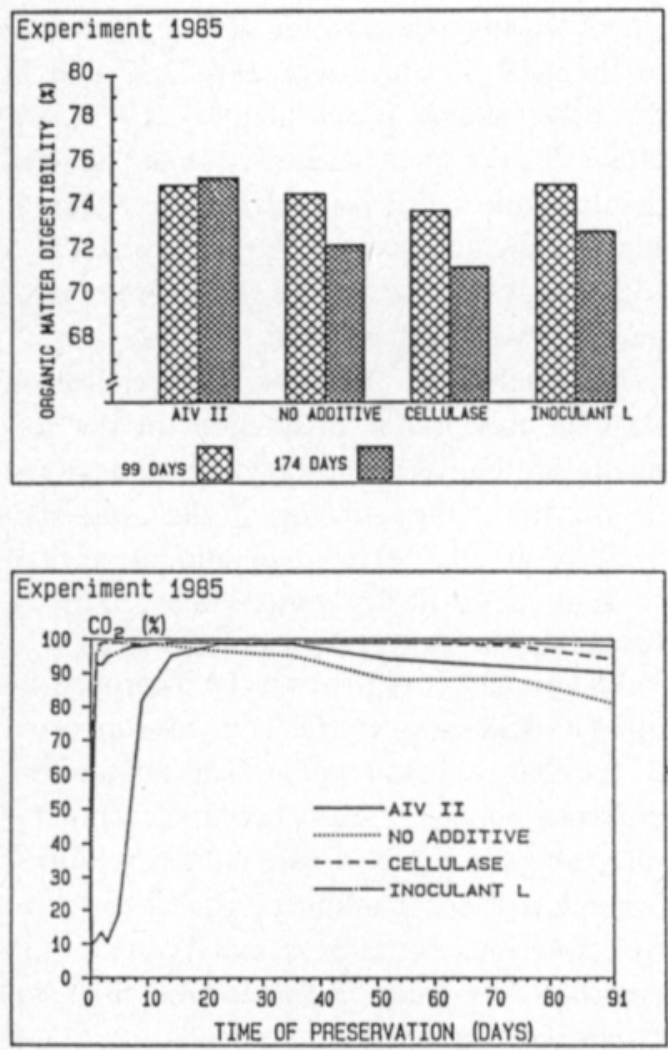

and cadaverine were detected after 8 days from the preservation. The lowest content of tyramine was found in the inoculated silage and the highest in the AIV II silage. Putrescine and cadaverine were highest in the untreated silage (Table 2). Generally the amine contents remained very low in every silage compared with the earlier experiment (SETÄLÃ et al. 1986) indicating that the protein degradation had been low in these silages. SetÄLÄ et al.

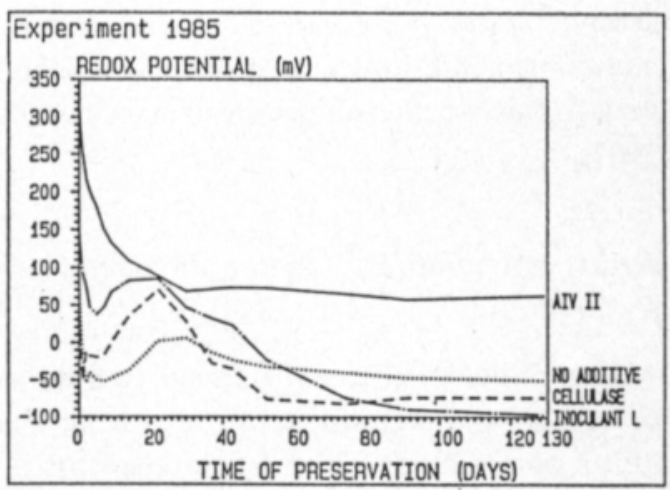

Fig. 3. The changes in the experimental silages made with AIV II solution, no additives, cellulase and inoculant. 
(1987) observed that the lowest amine content was found in the AIV II treated silage which indicated the most homolactic fermentation in that particular experimental silage in which the raw material was very wet and the sugar content low.

The ammonia- $\mathrm{N} \%$ from total- $\mathrm{N}$ was below $8 \%$ in every silage during the whole preservation period. The most proteolytic fermentation was found in the untreated silage and it contained also the highest amount of ammonia (Fig. 2). The nitrate content had decreased during preservation (Table 1). The reduction of nitrate to ammonia is possible in the silage and it can be caused by plant nitrate reductase and enterobacteria, clostridia and lactobacilli (Spoelstra 1985). According to Spoelstra (1985) enterobacteria would mainly be responsible for the reduction of nitrate in silages. In these experimental silages no butyric acid was found and the clostridia content was very low. The reduction of nitrate was only partial. The coliform bacteria could only work during the first preservation days because the anaerobic conditions were obviously reached very rapidly in the silages (RAURAMAA et al. 1987).

\section{Redox potential $\left(E_{h}\right)$, carbon dioxide, temperature}

The ability of the environment to oxidize or reduce is determined by measuring the redox potential, $\mathrm{E}_{\mathrm{h}}$. The development of $\mathrm{E}_{\mathrm{h}}$ in the silages is presented in Fig. 3. In the untreated, cellulase treated and inoculated silages the $E_{h}$ falls rapidly during the first days of preservation to the value of about -20 to -50 millivolts. The redox potential fell slowly in AIV II silage to a value of about +50 to +60 millivolts and remained there throughout the whole ensiling. The greatest decrease in the $\mathrm{E}_{\mathrm{h}}$ occurred in the inoculated silage. In this experiment the readings of the redox potentials in the AIV II silage were of the same kind as was earlier reported on good silages by Moisıo (1979). For the lactic acid fermentation Moisio reported $\mathrm{E}_{\mathrm{h}}+120-$ +110 millivolts and for butyric silages -50 to -200 millivolts.

In the inoculated silage the formation of carbon dioxide was slower than in the other fermented silages in which oxygen was consumed and carbon dioxide was produced together with the other gases within a couple of ensiling days (Fig. 3). It is possible that the lactic acid bacteria added inhibited the growth of enterobacteria and other initial bacteria of grass, because the respective condition was reached in the inoculated silage in two weeks. In the AIV II silage the delay was clear and took three weeks. It is well known that when formic acid is applied to the sward, there is an initial repression in respiratory enzymes and in all bacteria, and a consequent inhibition of temperature rise (LINDGREN et al. 1983, Henderson et al. 1972).

The temperature of the silages increased only by $1-4$ degrees during the period between the harvesting and the closing of the silos. During preservation the temperature in the AIV II silage was $21-22^{\circ} \mathrm{C}$ and in the other silages it reached $31^{\circ} \mathrm{C}$ (Fig. 3). However, the later development of the temperature and redox potential in the different silages indicated that the entry of oxygen into fodder was prevented. The silages were compact and carefully covered.

In conclusion, the present investigation showed only minor differences in the fermentation between untreated and inoculated or enzyme-treated silages, if the grass had a $20 \%$ dry matter content and more than $15 \%$ sugar in the dry matter. The quality of fermentation, however, was improved.

The quality could further be improved by using an acid preservative. This was supported by the changes in the organic acids, ammonia, buffering capacity, redox potential, temperature, and finally by a better digestibility of organic matter. It might be useful to try to find solutions for preventing frequent, too vigorous fermentation in inoculated or enzyme-treated silages. 
Acknowledgements. The authors would like to thank the staff of the Agricultural Research Centre and the chemical and microbiological groups in the Research

\section{References}

Autrey, K.M., McCaskey, T.A. \& Little, J.A. 1975. Cellulase digestibility of fibrous materials treated with Trichoderm Viride Cellulase. J. Dairy Sci. 58: 67-71.

Breirem, K. \& Ulvest., O. 1960. Ensiling methods. Herbage Abstracts 30 (1): 1-8.

Dellaglio, F. 1985. Lactic acid bacteria in silage fermentation. Microbiologie - Aliments - Nutrition 3: 91-104.

Ghosh, Р.В. \& Whitehouse, M.W. 1968. -7-Chloro-4nitrobenzo-2-oxa-1,3-diazole: a new fluorigenic reagent for amino acids and other amines. Biochem. J. 108: $155-156$.

Heikonen, M., Moisio, T. \& Kreula, M. 1979. Assessment of the quality of AIV silage. Valio laboratory Publications no. 4: 30-56.

Henderson, A.R. \& McDonald, P. 1977. The effect of cellulase preparations on the chemical changes during the ensilage of grass in laboratory silos. J. Sci. Fd. Agric. 28: 486-490.

Henderson, A.R., McDonald, P. \& Woolford, M.K. 1972. Chemical changes and losses during the ensilage of wilted grass treated with formic acid. J. Sci. Fd. Agric. 23: 1079-1087.

Imai, K. \& Watanable, Y. 1981. Fluorimetric determination of secondary amino acids by 7-fluoro-4-nitrobenzo1,3-diazole. Anal. Chim. Acta 130: 377-383.

Leatherwood, J.M., Mochirı, R.D., Stone, E.J. \& Tномаs, W.E. 1963. Cellulose degradation by enzymes added to ensiled forages. J. Dairy Sci. 46: 124-127.

Lindgren, S., Lingvall, P., Kaspersson, A., De Kartzow A. \& Rydberg, E. 1983. Effect of inoculants, grain and formic acid on silage fermentation. Swedish J. agric. Res. 13: 91-100.

Lindgren, S., Pettersson, K., Jonsson, A., Lingvall, P. \& Kaspersson, A. 1985. Silage inoculation. Swedish J. agric. Res. 15: 9-18.

Mossı, T. 1979. Some measurements in silage during fermentation. Valio laboratory publications no. 4: $57-80$.

Nehring, K., Heinz, D. \& Friedel, K. 1983. Der Einfluss von Zellulase auf die Silierung von einweissreichen Futterstoffen. Arch. Tierernàhr., Berlin 33 (2-3): $251-258$.

Playne, M.J. \& McDonald, P. 1966. The buffering constituents of herbage and of silage. J. Sci. Food Agric. 17: 264-268.

Rauramaa, A., Setal.a, J., Moisio, T., Sivelá, S., HeikKILA, T. \& LAMPILA, M. 1987. The effect of inoculants and cellulase on the fermentation and microbiological composition of grass silage. Part 2. Microbiological and Development Department of Valio for their technical assistance.

changes in the silage. J. Sciest. Agric. Soc. Finl. 59: 371-377.

Rooke, J.A., Bell, S.A. \& Armstrong, D.E. 1985. The chemical composition of grass silages prepared with and without pre-treatment with inoculants containing Lactobacillus plantarum. Animal Feed Sci. and Technol. 13: 269-279.

Seale, D.R., Henderson, A.R., Pettersson, K.O. \& LOWE, J.F. 1986. The effect of addition of sugar and inoculation with two commercial inoculants on the fermentation of lucerne silage in laboratory silos. Grass and Forage Science 41: 61-70.

Setälä, J., Moisıo, T. \& RauramaA, A. 1986. Use of inoculants and enzymes as grass silage additives. IDFmeeting in Haag 1986.

Setālā, J., Moisio, T., Rauramaa, A., Sivelá, S., Tol. VONEN, V. \& LAMPILA, M. 1987. Development of fermentation in low-sugar grass ensiled with inoculants. (in print)

Somocyı, M. 1945. A new reagent for the determination of sugars. J. Biol. Chem. 160: 61 .

Spoelstra, S.F. 1985. Nitrate in silage. Grass and Forage Science 40: 1-11.

Steingass, H. 1983. Bestimmung des energetischen Futterwertes von wirtschaftseigenen Futtermitteln aus der Gasbildung bei der Pansenfermentation in vitro. Thesis, Universităt Hohenheim. 188 p.

Vaisto, T., Heikonen, M. \& Kreula, M. 1978. The use of cellulases for increasing the sugar content of AIVsilage. J. Scient. Agric. Soc. Finl. 57 (3) 139-146.

Vanbelle, M. \& Bertin, G. 1985. Ensilage, new biological aspects. Sanofi Sante Animale 107 p.

Vanbelle, M., Bertin, G. \& Helling, Ph. 1985. Recent developments in biological methods of silage conservation. Laboratoire de Biochemie de la Nutrition Louvain -1a-Neuve Belgigue. Publication 39: 1-12.

VIRTANEN, A.I. 1933. The AIV method of processing fresh fodder. Empire Journal of Experimental Agriculture 1: 143-155.

WoOlford, M.K. 1984. The silage fermentation. New York. 350 p.

Woolford, M.K. \& SAwczyc, M.K. 1984 a. An investigation into the effect of cultures of lactic acid bacteria on fermentation in silage 1. Strain selection. Grass and Forage Sci. 39: 139-148.

Woolford, M.K. \& Sawczyc, M.K. 1984 b. An investigation into the effect of cultures of lactic acid bacteria on fermentation in silage. 2. Use of selected strains in laboratory-scale silages. Grass and Forage Sci. 39: 149-158.

Ms received June 17,1987 


\section{SELOSTUS}

\section{Maitohappobakteeri- ja sellulaasientsyymi- lisäyksen vaikutus nurmisäilörehun käymiseen ja mikrobiologiseen koostumukseen. \\ I Biokemialliset muutokset säilörehussa}

\author{
Aino Rauramaa, Jouko Setälä, Tauno Moisio \\ Valio Meijerien Keskusosuusliike \\ Tutkimus- ja tuotekehittelyosasto \\ PL 176, 00181 Helsinki
}

\section{Terttu Heikkilä ja Martti Lampila}

Maatalouden Tutkimuskeskus

Kotieläinhoidon Tutkimuslaitos

31600 Jokioinen

Neljä koesäilörehua à 45000 kg tehtiin laakasiioihin kesällä 1985 Maatalouden Tutkimuskeskuksen Lintupajun koetilalla. Raaka-aine oli koiranheinä-timoteinurmea (1:2), jonka kuiva-ainepitoisuus oli $20,3 \%$. Kuivaaineessa oli raakakuitupitoisuus $21,9 \%$, raakavalkuaispitoisuus 17,6 \% ja pelkistãviă sokereita 15,6\%. Nurmi korjattiin kelasilppurilla, jossa varsinaisiin koerehuihin lisättiin joko maitohappobakteereita tai sellulaasientsyymiă. Vertailurehut tehtiin samasta raaka-aineesta, toinen ilman säilöntäainetta, toiseen lisättiin AIV II -liuosta 5,21 rehutonnille. Säilöntäaika oli 174 päivăă. Käymistapahtumia rehuissa seurattiin säilönnän aikana mittaamalla lämpötilat ja redokspotentiaalit suoraan rehu- massasta sekä ottamalla näytteet kairaten ja analysoimalla ne.

Aistinvaraisen arvion mukaan kaikki säilörehut olivat hyviä. Kemialliset tulokset taas osoittavat vain pieniă eroja käymisten määrissä maitohappobakteeri- ja entsyymilisăyksellă sekă ilman săilöntäainetta valmistetuissa rehuissa. Kuitenkin maitohappo-bakteerilisảys ja sellulaasikäsittely paransivat käymisten laatua. Laatu parani edelleen kảytettäessả AIV II -liuosta. Tămă ilmenee selvăsti pH-arvosta, sokeri- ja ammoniakki-pitoisuudesta, puskurikapasiteetista, lämpötilasta ja lopulta rehun paremmasta orgaanisen aineen sulavuudesta. 